\title{
PEMBERDAYAAN MASYARAKAT MELALUI USAHA PERTAMBAKAN BERDASARKAN POTENSI KUALITAS AIR SUNGAI KRUENG CUNDA DI KOTA LHOKSEUMAWE
}

\section{Ekamaida ${ }^{1}$}

\section{Email: ekamaida@unimal.ac.id}

\begin{abstract}
ABSTRAK
The city of Lhokseumawe is located in the coastal area of Malacca Strait separated through the river Krueng Cunda which forms a strait so potential to be used as aquaculture area. Determination of location of research by purposive sampling at River Krueng Cunda by setting five observation station. Sampling is done directly (insitu) location without repetition The result of water quality measurement at research location is measurement of chemical physics factor obtained average temperature $290 \mathrm{C}$ to $330 \mathrm{C}$, dissolved oxygen (DO) $6,3(\mathrm{mg} / 1)$ to $7,7(\mathrm{mg} / 1)$, the $\mathrm{pH}$ of the waters to five stations is in the range of 7.3 to 7.9 and the salinity in the station ranges from $12 \%$ to $28 \%$. The quality of Krueng Cunda River water is still within the quality standard threshold according to Government Regulation No. 82 of 2001 on water quality management and water pollution control, so potential to be developed into aquaculture area.
\end{abstract}

Keywords: water quality, agriculture area, cunda river

\section{PENDAHULUAN}

\section{Latar Belakang}

Pengelolaan lingkungan pesisir sebagai lahan budidaya untuk memacu kembali produksi udang secara berlanjut,harus dilakukan dengan mempertimbangkan kemampuan alami yang dibentuk oleh keragaman hayati.Perbaikan mutu lingkungan secara artifisial akan berbiaya dan beresiko tinggi, sehingga konsep pemulihan secara alami merupakan alternatif yang paling baik. Komponen biotik dan abiotik di kawasan pesisir memiliki peran secara spesifik,namun saling berkaitan satu dengan lainnya untuk mempertahankan kemantapan dan kesuburan lahan budidaya di kawasan pesisir. Oleh karena keseimbangan suatu ekosistem perairan termasuk lahan budidaya dapat menjadi indikator kondisi ekologi terkini pada suatu kawasan tertentu. Dengan Permasalahan untuk meningkatkan kesuksesan panen udang dan meningkatkan hasil panen udang menjadi permasalahan yang utama dalam penelitian ini. Penelitian ini bertujuan untuk melihat kualitas air pada kawasan Sungai Krueng Cunda yang menjadi sumber air untuk budidaya tambak. Hasil penelitian ini diharapkan menjadi informasi bagi pengelolaan dan pemanfaatan lingkungan di kawasan Pesisir lokasi penelitian untuk kegunaan lahan budidaya tambak dan mengoptimalkan hasil panen

\section{BAHAN DAN METODE}

\section{Waktu dan Tempat Penelitian}

Penelitian ini dilakukan pada bulan Mai 2017 sampai Juni 2017 di sepanjang aliran Sungai Krueng Cunda yang merupakan sumber air bagi areal pertambakan kota Lhokseumawe Aceh Indonesia. Pengambilan sampel dilakukan pada 5 stasiun pengamatan secara "Purposive Sampling. Penelitian

\footnotetext{
${ }^{1}$ Staff Pengajar Fakultas Pertanian Universitas Malikussaleh
} 
dilakukan, secara langsung di lokasi (exsitu) untuk parameter fisika dan untuk parameter kimia di Laboratorium Ekologi Fakultas Matematatika dan ilmu pengetahuan alam (FMIPA) Unsyiah.

\section{Alat dan Bahan penelitian}

Adapun alat dan bahan yang akan digunakan pada penelitian ini berupa, alat untuk pengukuran kondisi fisik dan kimia lingkungan air , GPS (Global Position System) untuk menentukan koordinat stasiun penelitian , Stopwatch, kertas label, spidol, kamera digital, refraktometer, thermometer, $\mathrm{pH}$ meter tipe Lutron $p H-201$, dan DO meter tipe Lamotte DO 6.

\section{Metode Pengambilan Sampel}

Pengambilan sampel dilakukan dengan metode transect line plots (English et al.,1994) secara acak sistematik. Setiap stasiun pengamatan dibagi menjadi tiga substasiun berupa garis transek 100 meter yang diusahakan tegak lurus dengan garis pantai . Sampel air diambil pada tiap stasiun tanpa pengulangan secara langsung (insitu) dan pengambilan Subtrat untuk parameter kimia dilakukan dengan mengunakan pipa paralon berdiameter 4 inch sampai kedalaman $10 \mathrm{~cm}$, kemudian subtrat tersebut disimpan dalam plastik dan diberi label untuk selanjutnya dianalisis di laboratorium.

\section{Analisis data}

\section{Analisis kuaitas air}

Untuk melakukan analisis kualitas air dibahas secara deskriptif dan membandingkan parameter kualitas air dengan baku mutu air menurut PP. RI. No. 82 tahun 2001.

\section{HASIL DAN PEMBAHASAN}

\section{Kondisi Geografis Lokasi Penelitian}

Secara geografis lokasi penelitian berada pada kawasan Kota Lhokseumawe yang berada pada posisi $04^{\circ} 54^{\prime}-05^{\circ} 18^{\prime}$ Lintang Utara dan $96^{\circ}$ $20^{\prime}-97^{\circ} 21^{\prime}$ Bujur Timur, yang diapit oleh Selat Malaka. Kota Lhokseumawe memiliki luas wilayah $181,10 \mathrm{Km}^{2}$, yang secara administratif meliputi 4 kecamatan. Salah satu kecamatan yang dipilih untuk menjadi lokasi penelitian ini yaitu Kecamatan Banda Sakti. Lokasi penelitian secara lebih akuratnya adalah lokasi pertambakan disekitaran aliran sungai cunda yang masuk kedalam kawasan kecamatan Banda Sakti dengan batas - batas sebagai berikut : Sebelah Utara dengan Selat Malaka. Sebelah Barat dengan Kecamatan Dewantara Kabupaten Aceh Utara. Sebelah Selatan dengan Kecamatan Kuta Makmur Kabupaten Aceh Utara.Sebelah Timur dengan Kecamatan Syamtalira Bayu Kabupaten Aceh Utara. Adapun aliran Sungai Krueng Cunda yang dijadikan lokasi penelitian melewati 3 desa antara lain Pusong Lama, Uten Bayi dan Ujong Blang.

Banyaknya Desa pada kecamatan Banda Sakti sebanyak 18 desa dengan luas wilayah Kecamatan Banda Sakti : 11,24 $\mathrm{Km}^{2}$. Penggunaan lahan terbesar di Kota Lhokseumawe adalah untuk permukiman seluas 10877 ha atau sekitar $60 \%$ dari luas yang ada. Kebutuhan lahan yang menonjol adalah untuk usaha kebun campuran 4.590 ha atau sekitar $25,35 \%$, di samping untuk kebutuhan persawahan seluas 3747 ha atau sekitar 21\%. Untuk kebutuhan perkebunan rakyat telah dimanfaatkan seluas 749 ha atau sekitar 4\% dan untuk perairan darat 623 ha atau 3\%. Secara demografi jumlah penduduk kecamatan Banda Sakti pada tahun 2014 adalah 
sebanyak 80769 jiwa. Gambar 1 menunjukkan peta geografis lokasi penelitian.

\section{Parameter Kualitas Air}

Hasil pengukuran terhadap Parameter kualitas air wilayah penelitian dapat dilihat pada (Tabel 3) meliputi : suhu $\left(29{ }^{0} \mathrm{C}-33{ }^{0} \mathrm{C}\right)$, Saliniras ( $12 \mathrm{ppt}-$ 28ppt ), Dissolved Oxygen / DO (6,3 (mg/l - 7,7 (mg/l). C-organik $(0.126 \%$ $3.73 \%), \mathrm{pH}(7,30-7,90)$, $\mathrm{N}$ total $(1,4$ $3,6 \mathrm{mg} / \mathrm{l})$. adapun tekstur subtract wilayah penelitian. Pada stasiun 1, 3 dan 4 memiliki tekstur substrat lempung berpasir, stasiun 2 dan 5 memiliki tekstur subtract yaitu pasir. (Tabel 1).

\section{Perbandingan Parameter Kualitas Air Sungai Krueng Cunda dengan PP No 82 Tahun 2001}

suhu air pada lima stasiun penelitian berkisar $29{ }^{\circ} \mathrm{C}$ sampai $33{ }^{\circ} \mathrm{C}$. Menurut PP No.82 Tahun 2001 tentang pengelolaan kualitas air dan pengendalian pencemaran air. Baku mutu badan air golongan III menyatakan bahwa temperatur air normal memiliki deviasi 3 dari keadaan temperatur alamiah dilingkungan setempat.Kisaran suhu untuk kegiatan budidaya air tawar yang baik untuk menunjang pertumbuhan optimal 28$32^{\circ} \mathrm{C}$ (Tatangindatuet al., 2013).

Akan tetapi wilayah penelitian merupakan kawasan estuaria dan pengambilan sampel air dilakukan secara insitu tanpa pengulangan. Suhu air diperairan estuari cenderung lebih bervariasi jika dibandingkan dengan suhu air dipantai sekitarnya. Hal ini disebabkan karena volume air di estuari adalah lebih kecil dan luas permukaannya lebih besar, sehingga pada kondisi yang ada air estuari akan lebih cepat panas dan lebih cepat dingin (Suyasa , 2010).
Salinitas air pada kelima stasiun berkisar antara $12 \mathrm{ppt}-28 \mathrm{ppt}$ hal ini menunjukkan bahwa nilai tersebut masih dalam batas toleransi untuk kehidupan biota perairan. Nilai salinitas perairan tawar biasanya kurang dari $0,5 \mathrm{ppt}$, perairan payau antara $0,5 \mathrm{ppt}-30 \mathrm{ppt}$, dan perairan laut $30 \mathrm{ppt}-40 \mathrm{ppt}$. Pada perairan hipersaline, nilai salinitas dapat mencapai kisaran 40 ppt - 80 ppt. Pada perairan pesisir, nilai salinitas sangat dipengaruhi oleh masukan air tawar dari sungai (Effendi, 2003) Lebih lanjut Suyasa (2010) mengatakan bahwa, salah satu ciri dominan dari perairan estuari adalah terjadinya fluktuasi salinitas yang kemudian membentuk gradient, dimana gradient salinitas ini sangat tergantung pada musim, topografi estuari, pasang surut dan jumlah air tawar.

Nilai oksigen terlarut daerah penelitian berkisar antara 6,3 (mg/l) sampai 7,7 (mg/l). Kisaran nilai DO pada kelima stasiun masih dalam kisaran nilai toleransi kawasan budidaya. Berdasarkan PP No. 82 Tahun 2001, kandungan DO di sungai Ujong Pacu masih dalam ambang batas baku mutu kelas 3 yang diperuntukkan sebagai kegiatan budidaya air tawar yaitu DO > $4 \mathrm{mg} / \mathrm{L}$. Kadar DO dari stasiun tiap stasiun cukup bervariasi, hal ini dipengaruhi oleh kondisi lingkungan seperti kecepatan arus yang makin ke hilir semakin lambat, begitu juga dengan kedalaman semakin ke hilir semakin besar, dan turbulensi masih mungkin terjadi. Kadar oksigen terlarut juga berfluktuasi secara harian (diurnal), musiman, tergantung pada pencampuran (mixing) dan pergerakan (turbulence) massa air, aktivitas fotosintesis, respirasi, dan limbah (effluent) yang masuk ke badan air (Effendi 2003).

Kandungan C-organik pada wilayah penelitian pada setiap stasiun bervariasi dengan kisaran nilai rataan 
$0.126 \%-3.73 \%$. Secara keseluruhan nilai kandungan organik substrat yang didapat dari kelima stasiun penelitian tergolong sangat rendah dan sedang. Adanya perbedaan kandungan $\mathrm{C}$ organik diduga karena tipe sedimen yang berbeda ukuran partikelnya antar stasiun sehingga mempengaruhi banyak sedikitnya kandungan $\mathrm{C}$-organik yang terkandung. Hal ini didukung oleh pernyataan Nybakken (1992), bahwa pantai berlumpur cenderung untuk mengakumulasi bahan organic.

Hasil pengukuran pH selama penelitian menunjukan nilai tingkat keasaman $(\mathrm{pH})$ masih dalam kisaran yang baik yaitu 7,30 - 7,90 termasuk bersifat alkalis (Poernomo, 1988). Berdasarkan nilai $\mathrm{pH}$ yang diperoleh maka perairan tersebut layak untuk mendukung kehidupan organisme budidaya serta memberikan indikator bahwa lahan budidaya bukan merupakan tanah sulfat masam yang sangat membutuhkan pengelolaan. Secara spesifik untuk menjadi lahan budidaya hal ini sesuai baku mutu air berdasarkan PP No. 82 Tahun 2001 dengan nilai $\mathrm{pH}$ yaitu 6-9. Kondisi perairan yang memiliki $\mathrm{pH}$ netral sangat bagus bagi ekosistem air dan baik untuk pertumbuhan dan perkembangan organisme air termasuk makrozoobenthos.

Kandungan nitrat yang didapat pada kelima stasiun berkisar 1,4 - 3,6 $\mathrm{mg} / \mathrm{l}$. jumlah rata-rata kandungan nitrat yang didapat ini masih berada dibawah ambang batas baku mutu air berdasarkan PP No. 82 Tahun 2001 dengan nilai kandungan nitrat yaitu $10 \mathrm{mg} / \mathrm{l}$. Hasil ini menunjukkan bahwa kandungan nitrat yang didapat tidak berbahaya bagi kualitas air dan lingkungan diwilayah penelitian. Hal ini sesuai dengan literatur Siregar (2011) yang menyatakan bahwa keberadaan senyawa nitrogen dalam perairan dengan kadar yang berlebihan dapat menimbulkan permasalahan pencemaran.

\section{KESIMPULAN}

Kualitas air Sungai Krueng Cunda berpotensi masih dalam ambang batas baku mutu menurut PP No 82 Tahun 2001 tentang pengelolaan kualitas air dan pengendalian pencemaran air sehingga dapat dijadikan dasar bagi pemberdayaan masyarakat untuk mengalakkan usaha pertambakan.

\section{DAFTAR PUSTAKA}

Ardi,

$\begin{array}{lr}2002 . & \text { Pemanfaatan } \\ \text { Makrozoobentos } & \text { Sebagai } \\ \text { Indikator Kualitas } & \text { Perairan } \\ \text { Pesisir. Program Pasca Sarjana } \\ \text { (S3) IPB. Bogor. }\end{array}$

Barus, T. A., Arjuna, J., Siregar, A. Z., Martopo, J. H., dan Betrit J. 2001. Organisme Perairan ( Benthos dan Plankton). Jurusan Biologi Fakultas Matematika dan Ilmu Pengetahuan Alam Universitas Sumatera Utara, Medan.

Darojah,Yuyun.2005. Keanekaragaman Jenis Makrozoobentos di Ekosistem Perairan Rawa pening Kabupaten Semarang.

Fachrul, F.M. 2007.Metode Sampling Bioekologi. Bumi Aksara, Jakarta.

Fitriana, Y. R. 2006. Keanekaragaman dan kelimpahan Makrozoobentos di Hutan Manggrove Hasil Rehabilitasi Taman Hutan Raya Ngurah Reli Bali. Biodeversitas. 7 (1) : 67-72.

Handayani, S. T. Suhato B, dan Marsoedi. 2001 Penentuan Status Kualitas Perairan 
Sungai Brantas Hulu Dengan

Biomonitoring

Makrozoobentos : Tinjauan

Dari Pencemaran Bahan

Organik, Biosains. 1 (1).

Helmizuryani.2010. Studi Kualitas Air pada Kanal di Kota Terpadu Mandiri (KTM) RambutanParit kabupaten Ogan Ilir untuk Mendukung Pengembangan Budidaya Ikan dalam Keramba. Tesis.Palembang: Universitas Sriwijaya.

Kusrini, D. M. 1998. Komposisi dan Struktur Komunitas Keong Potamididae di Hutan Mangrove Teluk Hurun Kecamatan Padang Cermin, Kabupaten Lampung Selatan. [Skripsi]. Jurusan Manajemen Sumberdaya Perairan Fakultas Perikanan. Institut Pertanian Bogor. Mangrove; Jakarta. hlm 1-2. dalam Sirante, R. 2011. Studi Struktur Komunitas Gastropoda di Lingkungan Perairan Kawasan Mangrove Kelurahan Lappa dan Desa Tongke - Tongke, Kabupaten Sinjai. hlm 1-12.

Maulana, Fauzan. 2010. Pemanfaatan Makrozoobentos Sebagai Indikator Kualitas Perairan Pesisir. Michael, P. Metode Ekologi Untuk Penyelidikan Ladang dan Laboratorium. Dialihbahasakan oleh Yanti R.Koestoer dan Sahati Suharto.1995. Jakarta: Penerbit Universitas Indonesia (UIPress).

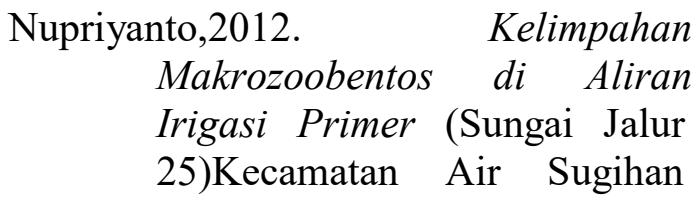

OKI dan Sumbangannya Pada Pembelajaran Biologi di SMA.

Nybakken, J. W. 1988. Biologi Laut. Suatu Pendekatan Ekologis. Diterjemahkan dari Marine Biology an Ecological Approach oleh M. Eidman. PT Gramedia Pustaka Utama. Jakarta. hlm 1-18. dalam Taqwa, A. 2010. Analisis Produktivitas Primer Fitoplankton dan Struktur Komunitas Fauna Makrobenthos Berdasarkan Kerapatan Mangrove di Kawasan Konservasi Mangrove dan Bekantan Kota Tarakan. [Tesis] Kalimantan Timur. Universitas Diponegoro Semarang. hlm 11-34.

Onrizal.2005.Ekosistem Sungai Dan Bantaran Sungai. Medan:Universitas Sumatra utara.

Odum, E.P. 1994. Dasar-Dasar Ekologi. Edisi Ketiga. Penerjemah : Samingan, T. UGM Press. Yogyakarta.

Peraturan Pemerintah Republik Indonesia Nomor 82 Tahun 2001. Pengelolaan Kualitas Air dan Pengendalian Pencemaran Air. Jakarta.

Petrus rani pong - masak, andi marsambuana pirzan, 2006. Komunitas Makrozoobentos pada Kawasan Budidaya Tambak di Pesisir Malakosa Parigi - Moutong, Sulawesi Tengah, Jurnal Biodiversitas, Volume7, Nomor 4, Halaman: 354-360, Balai Riset Perikanan Budidaya Air Payau, Maros, Sulawesi Selatan 90512, Oktober 2006. 
PT.SATWINDU

UTAMA,2009.

Pekerjaan Enginering Design (DED) Pengerukan Alur Pelayaran di Kanal Air Sugihan Kanan (Sumatra Selatan). http://www.google.co.id.

Diakses tanggal 21 Maret 2011.

Quijon, P. and E. Jaramillo. 1993. Temporal variability in the intertidal macroinfauna in the Queule Rever Estuary, SouthCentral Chilie. Estuarin Coastal and Shelf Science. 37:655-667.

Rosmelina, S. D.2009. Studi Keanekaragaman

Makrozoobentos Di Aliran Sungai Padang Kota Tebing Tinggi. Skripsi. Universitas Sumatera Utara, Medan.

Rosyadi, Nasution, S., Thamrin. 2009. Distribusi Dan Kelimpahan Makrozoobentos di Sungai Singingi Riau. Ilmu Lingkungan. 3(1) : 58-73.

Salmin, 2005. Oksigen Terlarut (DO) dan Kebutuhan Oksigen Biologi (BOD) Sebagai Salah Satu Indikator Untuk Menentukan Kualitas Perairan. Oseana. 30 (3) : 21-26.

Setiawan, D. 2010. Struktur Komunitas Makrozoobentos Sebagai Bioindikator Kualitas Lingkungan Perairan Hilir Sungai Musi. Tesis. Institut Pertanian Bogor. Bogor.

Sinaga,Tiorinse.2009.Keanekaragaman Makrozoobentos Sebagai Indikator Kualitas Perairan Danau Toba Balige Kabupaten Toba Samosir.Tesis. Medan: Universitas Sumatera Utara.

Susiana. 2011. Diversitas dan Kerapatan Manggrove,
Gastropoda Dan Bivalvia Di

Estuari Perancak,Bali.

Skripsi.Universitas

Hasanuddin. Makasar.

Suwignyo, S., Widigno, B. Wardianto, Y., Krisanti, M. 2005b. Avertebrata Air Jilid 1. Penebar Swadaya. Jakarta.

Suwignyo, S., Widigno, B. Wardianto, Y., Krisanti, M. 2005c. Avertebrata Air Jilid 2. Penebar Swadaya. Jakarta.

Suwondo, Elya F., Dessy dan Mahmud A. 2004. Kualitas Biologi Perairan Sungai Senapelan, Sago Dan Sail di Kota Pekanbaru Berdasarkan Bioindikator Plankton dan Bentos. Biogenesis.

Suyasa, I. N, Moch, Nurhudah dan Sinung, R. 2010. Ekologi Perairan. Penerbit : STP Press, Jakarta.

Syamsurisal, 2011. Studi Beberapa Indeks Komunitas Makrozoobentos Di Hutan Manggrove Kelurahan Coppo Kabupaten Baru. Skripsi. Jurusan Perikanan Fakultas Ilmu Kelautan dan Perikanan Universitas Hasanuddin, Makasar.

Tarigan, L. C.2009.Studi Keanekaragaman

Makrozoobentos di Danau Lau Kawar Desa Kuta Agung Kecamatan Simpang Empat Kabupaten Karo.Skripsi. Medan: USU.

Wardoyono, E. R. P., dan Junardi. 2008. Struktur Komunitas dan Karakteristik Substrat Cacing Laut (Polychaeta) di Perairan Pantai Manggrove Peniti, 
Kalimantan

Biodiversitas. 9(3) : 213-216.

Wijayanti, M. H. 2007. Kajian Kualitas Perairan di Pantai Kota Bandar Lampung Berdasarkan Komunitas Hewan Makrozoobentos. Tesis.
Universitas Semarang.

Krebs, C. 1989. Experimental Analysis of Distribution and Abudance. Third Edition. Harper and Row Publisher. New York.

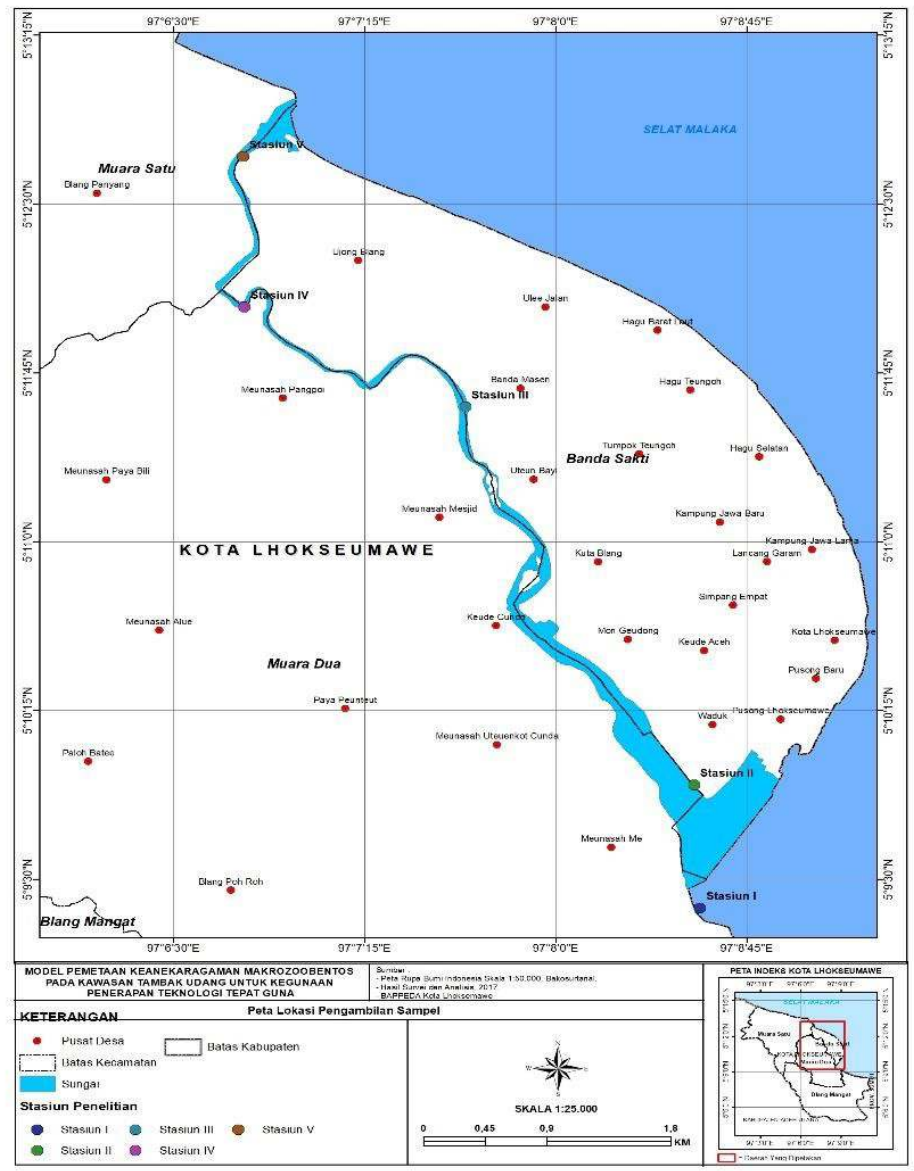

Gambar 1. Peta Lokasi wilayah penelitia 
Tabel 1. Parameter Kualitas air

\begin{tabular}{|c|c|c|c|c|c|c|}
\hline \multirow{2}{*}{ NO } & \multirow{2}{*}{ PARAMETER } & \multicolumn{5}{|l|}{ STASIUN } \\
\hline & & 1 & 2 & 3 & 4 & 5 \\
\hline 1 & Suhu & 33 & 32 & 29 & 32 & 33 \\
\hline 2 & Salinitas & 24 & 12 & 19 & 28 & 25 \\
\hline 3 & $\begin{array}{l}\text { DO } \\
\text { (Oksigenterlarut }\end{array}$ & 6,6 & 7,7 & 6,3 & 6,5 & 6,6 \\
\hline 4 & $\begin{array}{l}\text { Ph (Derajat } \\
\text { Keasaman) }\end{array}$ & 7,7 & 7,6 & 7,3 & 7,9 & 7,6 \\
\hline 5 & C Organic (\% & $0,25-1,59$ & $0,11-0,14$ & $\begin{array}{l}0,96- \\
2,310 .\end{array}$ & $1,51-6,98$ & $0,25-0,26$ \\
\hline 6 & N Total (\%) & $0,08-0,11$ & 0,06 & $0,09-0,13$ & $0,08-0,14$ & $0,03-0,04$ \\
\hline 7 & Subtrat & $\begin{array}{l}\text { Lempung } \\
\text { berpasir }\end{array}$ & Berpasir & $\begin{array}{l}\text { Lempung } \\
\text { berpasir }\end{array}$ & $\begin{array}{l}\text { Lempung } \\
\text { berpasir }\end{array}$ & Berpasir \\
\hline
\end{tabular}

